\title{
Time lag characteristics of sap flow in seed-maize and their implications for modeling transpiration in an arid region of Northwest China
}

\author{
BO Xiaodong ${ }^{1}$, DU Taisheng ${ }^{1 *}$, DING Risheng ${ }^{1}$, Louise COMAS ${ }^{2}$ \\ ${ }^{1}$ Center for Agricultural Water Research in China, China Agricultural University, Beijing 100083, China; \\ ${ }^{2}$ Water Management Research, United States Department of Agriculture, Agricultural Research Service, Building 011A, \\ BARC-West, Beltsville, MD 20705, USA
}

\begin{abstract}
Plant capacity for water storage leads to time lags between basal stem sap flow and transpiration in various woody plants. Internal water storage depends on the sizes of woody plants. However, the changes and its influencing factors in time lags of basal stem flow during the development of herbaceous plants including crops remain unclear. A field experiment was conducted in an arid region of Northwest China to examine the time lag characteristics of sap flow in seed-maize and to calibrate the transpiration modeling. Cross-correlation analysis was used to estimate the time lags between stem sap flow and meteorological driving factors including solar radiation $\left(R_{s}\right)$ and vapor pressure deficit of the air $\left(V P D_{\text {air }}\right)$. Results indicate that the changes in seed-maize stem sap flow consistently lagged behind the changes in $R_{s}$ and preceded the changes in $V P D_{\text {air }}$ both on hourly and daily scales, suggesting that light-mediated stomatal closures drove sap flow responses. The time lag in the maize's sap flow differed significantly during different growth stages and the difference was potentially due to developmental changes in capacitance tissue and/or xylem during ontogenesis. The time lags between stem sap flow and $R s$ in both female plants and male plants corresponded to plant use of stored water and were independent of total plant water use. Time lags of sap flow were always longer in male plants than in female plants. Theoretically, dry soil may decrease the speed by which sap flow adjusts ahead of shifts in $V P D_{\text {air }}$ in comparison with wet soil and also increase the speed by which sap flow adjusts to $R_{s}$. However, sap flow lags that were associated with Rs before irrigation and after irrigation in female plants did not shift. Time series analysis method provided better results for simulating seed-maize sap flow with advantages of allowing for fewer variables to be included. This approach would be helpful in improving the accuracy of estimation for canopy transpiration and conductance using meteorological measurements.
\end{abstract}

Keywords: seed-maize; sap flow; capacitance; transfer function model; time lag; stored water use

Citation: BO Xiaodong, DU Taisheng, DING Risheng, Louise COMAS. 2017. Time lag characteristics of sap flow in seed-maize and their implications for modeling transpiration in an arid region of Northwest China. Journal of Arid Land, 9(4): 515-529. doi: 10.1007/s40333-017-0024-4

\section{Introduction}

With the advantages of easy application and no calibration, the stem heat balance technique is widely used to measure the stem sap flow (Dzikiti et al., 2007; Vellame et al., 2010; Chirino et al., 2011; Swaef et al., 2012). Stem sap flow can directly indicate instantaneous water consumption (Sakuratani, 1981; Baker and van Bavel, 1987; Steppe et al., 2010), canopy transpiration, and

*Corresponding author: DU Taisheng (E-mail: dutaisheng@cau.edu.cn)

Received 2016-03-23; revised 2017-05-17; accepted 2017-06-02

(C) Xinjiang Institute of Ecology and Geography, Chinese Academy of Sciences, Science Press and Springer-Verlag Berlin Heidelberg 2017 
hydraulic conductance (Martin et al., 2001). Estimating diurnal canopy transpiration and conductance from stem sap flow data critically depends upon knowledge of the time lag between transpiration and water flux through the stem (Diawara et al., 1991; Granier and Loustau, 1994). Many studies of canopy transpiration and stomatal conductance have used stem sap flow directly without accounting for time lag (e.g., Köstner et al., 1992; Dye and Olbrich, 1993; Trambouze et al., 1998; Alarcón et al., 2003; Nicolas et al., 2005; Chang et al., 2006; Gong et al., 2007; Kume et al., 2012; Corona et al., 2013; Villalobos et al., 2013; Paudel et al., 2015). Nevertheless, it has been found that failure to account for time lag between stem sap flux and canopy transpiration can cause up to $30 \%$ errors in instantaneous canopy transpiration determined from these measurements (Phillips et al., 1999).

Time lag has been reported in many plants, including tropical forest trees (Meinzer et al., 2004; Motzer et al., 2005), pine trees (Granier et al., 1990; Čermák et al., 1995; Berbigier et al., 1996; Phillips et al., 1997; Saugier et al., 1997), orange trees (Dzikiti et al., 2007), and grapevines (Phillips et al., 1999). Previous studies indicated that the lags of basal stem sap flow should be mainly dependent on the total size of plant water storage capacity (Schulze et al., 1985; Ewers and Oren, 2000; Lhomme et al., 2001; Steppe and Lemeur, 2004; Meinzer et al., 2008). Water storage in plants organs causes water flow lag in the stem from several minutes to hours compared with leaf transpiration. Use of water stored in plants may allow leaves to operate at water potentials favorable for transpiration during peak daylight hours (Stratton et al., 2000; Maherali and DeLucia, 2001) or morning hours (Borchert, 1994), when canopy transpiration is subject to hydraulic limitations to water transport in plants. For woody species, the time lag depends on buffering capacity associated with water storage in trunks and branches (Landsberg et al., 1976; Edwards et al., 1986; Hunt and Nobel, 1987; Schulte, 1993; Dzikiti et al., 2007). Goldstein et al. (1998) found that the time lag for xylem water flux between upper branches and tree bases was positively associated with tree size in five tropical tree species (but see Oren et al., 1996; Phillips et al., 1999). If capacitance scales with plant size, then lags may not exist or may be small for herbaceous plants. In addition, older trees, which are generally larger and taller, often have longer lags (Hogg et al., 1997; Granier et al., 2000), and use more stored water than younger trees (Phillips et al., 2003), suggesting that capacitance varies with plant development. Internal water storage depended on the amount of sapwood associated with tree size (Stewart, 1967; Hinckley et al., 1978), thus older trees should have more water storage capacity and larger time lags. Čermák et al. (1976) indicated that time lags between stem and branch may also be dependent on anatomical characteristics of the vascular system. Thus, open questions remain on how time lags of basal stem flow will change with plant development in herbaceous plants.

In general, upper branch fluxes are often used as a surrogate for canopy transpiration (Goldstein et al., 1998; Hinckley et al., 1998). However, time lags between plant crown sap flux and crown transpiration may be much greater than the lags between the base of plant and crown (Schulze et al., 1985). Before branch sap fluxes can be used as surrogates for transpiration, more information on the temporal coupling between branch fluxes and foliage transpiration is needed (Wullschleger et al., 1998).

The arid region of Northwest China has developed into the largest seed-maize production area of China, but water shortage is the bottleneck for its long-term sustainability. Investigating time lags of sap flow in seed-maize will offer valuable information for accurate estimation of canopy transpiration. So we performed a study to determine temporal relationships between basal stem sap flow and meteorological driving variables. Determining the temporal coupling between water flux at the base of seed-maize plants and meteorological driving variables is needed to accurately estimate canopy transpiration or canopy gas exchange from sap flow measurements, and eventually scale up the time lag phenomena across many plants to obtain a field scale lag of water uptake in relation to evaporative demand. Using field crop sap flow and meteorological measurements in a mature seed-maize field, we applied cross correlation analysis to compare time lags due to solar radiation $\left(R_{s}\right)$ and vapor pressure deficit of the air $\left(V P D_{\text {air }}\right), R_{s}$ and $V P D_{\text {air }}$ being the two factors that were previously demonstrated to affect transpiration in seed-maize (Bo et al., 2015). The objectives of the present study were to investigate dynamic relationships between 
stem sap flow and meteorological driving variables $\left(R_{s}\right.$ and $\left.V P D_{\text {air }}\right)$ and also to analyze the effects of soil factors (i.e., soil water content) and plant factors (i.e., stored water use, plant growth, and interspecific differences) on the temporal coupling between basal stem flow and meteorological driving variables. We further presented an alternate technique to model field crops stem flow using meteorological measurements.

\section{Materials and methods}

\subsection{Experimental area and plant materials}

The experiment was conducted at Shiyanghe Experimental Station of China Agricultural University, located in Wuwei City, Gansu Province, China ( $37^{\circ} 52^{\prime} \mathrm{N}, 102^{\circ} 50^{\prime} \mathrm{E} ; 1581 \mathrm{~m}$ a.s.1.) during 21 April to 24 September, 2013. The average annual evaporation was $\sim 2000 \mathrm{~mm}$, and average annual duration of sunshine was more than 3000 hours. During the experimental period, the daily mean temperature was approximately $20^{\circ} \mathrm{C}$, and rainfall approximately $62 \mathrm{~mm}$. The driest month was July with a monthly rainfall of $10 \mathrm{~mm}$ and wettest month August with a monthly rainfall of $27 \mathrm{~mm}$. The soil in the $0-100 \mathrm{~cm}$ depth was classified as irrigated desert soil (Siltigic-Orthic Anthrosols), a sandy loam with a mean dry bulk density of $1.50( \pm 0.01) \mathrm{g} / \mathrm{cm}^{3}$ and with a field capacity of $0.290( \pm 0.003) \mathrm{cm}^{3} / \mathrm{cm}^{3}$. Seed-maize crops were irrigated to $95 \%$ of the field capacity when average soil water content in $0-100 \mathrm{~cm}$ depth was depleted to $75( \pm 2) \%$ of field capacity.

Seeds used for female and male plants were from genetically different lines displaying heterosis in the next generation. Seeds for both female and male plants were sown at 97,500 seeds/hm² density with 50-cm row spacing. Female plants were sown on 22 April, 2013 and male plants on 28 April, 2013. The planting proportion of female and male plants was 5:1. Female plants were detasseled 69 to 70 days after sowing (DAS). Male plants were left intact. For maize, maximum plant height is reached at tasseling (beginning of the heading stage). Plants were harvested on 12 September, 2013.

\subsection{Sap flow measurement}

Stem sap flow was measured from July to September using the heat balance method (Sakuratani, 1981) with the Dynagage Flow32-1K system (Dynamax, Houston, TX, USA). Five female plants and three male plants were sampled. Plants were randomly chosen within a $30-\mathrm{m}$ diameter circle (i.e., maximum length of the signal cable) from the data logger. Dynagage gauges (SGB16\&SGB19, Houston, TX, USA) consisting of a heating element, a thermopile and individual thermocouples, were installed at the second internode of maize above the root. Silicon film was put on the gauges to improve thermal exchange between the stem and the sensor. The gauges were wrapped in aluminum foil to shield them from rainfall, dew, and solar radiation. Gauges were moved to new plants every eight days to avoid plant damage due to sensor heating (Kjelgaard et al., 1997). The average value of instantaneous thermal conductance constant $\left(K_{s h}\right)$ during 02:00-05:00 (Beijing time) was used to calculate the sap flow, because the lowest $K_{s h}$ every day occurred in this period. Gauge outputs were collected every 1-min and recorded as 15-min means with a CR1000 data logger.

\subsection{Meteorological and soil moisture measurements}

Precipitation $(P, \mathrm{~mm})$, solar radiation $\left(R_{s}, \mathrm{~W} / \mathrm{m}^{2}\right)$, air temperature $\left(T_{a},{ }^{\circ} \mathrm{C}\right)$, relative humidity $(R H, \%)$, and wind speed $(\mathrm{m} / \mathrm{s})$ were measured every $15 \mathrm{~min}$ with an automatic weather station (Hobo Weather Station, USA) located in an adjacent open field less than $30 \mathrm{~m}$ away from the experimental plots. Vapor pressure deficit of the air $\left(V P D_{\text {air }}\right)$ was calculated as:

$$
V P D_{\text {air }}=(1-R H / 100) \times e_{s} \text {, }
$$

where, $e_{s}$ is the saturation vapor pressure $(\mathrm{kPa})$, which can be calculated as follow (Allen et al., 1998): 


$$
e_{s}\left(T_{a}\right)=0.6108 \exp \left(\frac{17.27 T_{a}}{T_{a}+237.3}\right) .
$$

Soil water content $(\theta)$ in the $0-100 \mathrm{~cm}$ depth was continually monitored using probes (model $\mathrm{ECH}_{2} \mathrm{O}-5 \mathrm{TE}$, Decagon Devices, Inc., Pullman, WA, USA) connected to a data logger (model Em50/R, Decagon Devices, Inc., Pullman, WA, USA). These sensors determine the volumetric water content by measuring the dielectric constant of the media using capacitance/frequency domain technology with a $70-\mathrm{MHz}$ frequency. Soil moisture probes were installed vertically through soil profile to the depth of $100 \mathrm{~cm}$ at $20-\mathrm{cm}$ intervals.

\subsection{Estimation of stored water use of seed-maize plants}

Water necessary for transpiration is supplied both by water stored inside the aerial part of plants and also by water absorbed from soil by roots. The time lag between canopy transpiration and basal stem sap flow is generally interpreted as the function of stored water used (Phillips et al., 2009). During the early daytime, for some plants, the water reserved in leaves, petioles and stem is mainly used for transpiration (Steinberg et al., 1990). This reserve is recharged during the night and the early morning hours (20:00-06:00) of the next day when transpiration resumes (Sellami and Sifaoui, 2003; Chuang et al., 2006). In this paper, daily stored water use was estimated as the amount of basal stem sap flow when $R_{s}$ reached zero in the evening (Morikawa, 1974; Phillips et al., 2003). This may underestimate total plant capacitance (Phillips et al., 2009) but serves as a relative measure of capacitance for genotypic and seasonal comparisons within this paper. Stored water use was calculated for each day and averaged on days with the same time lag and used to assess the relationship between stored water use and time lags of sap flow behind $R_{s}$.

\subsection{Data analysis and modeling}

Cross-correlation analysis (Oren et al., 1999; Phillips et al., 1999; Perämäki et al., 2001; Kume et al., 2008) was used to assess the relationship between time lags of maize stem sap flow and key environmental variables. The time lag of two time series that led to the maximum cross-correlation coefficient was obtained by shift at a time step of $15 \mathrm{~min}$. The cross-correlation analysis of sap flow approach enables studying the time lag during the growing season. It is important to compare with other approaches because the time lag may change depending on individual development and environmental factors (e.g., soil moisture). Thus, data of five days before irrigation (DAS 99-103) and five days after irrigation (DAS 71-75) were selected to calculate the time lag and to analyze the effect of soil water content on time lag of stem sap flow. Furthermore, this approach also helps assess the amplitude variation on stem sap flow in response to the environmental changes.

A general time series model, termed transfer function (ARIMAX) model (Box and Jenkins, 1976), was used to simulate and analyze fluctuations in stem sap flow. The general form of ARIMAX model is:

$$
\left\{\begin{array}{l}
S F_{t}=\frac{\Omega(B)}{E(B)} B^{b} \times X_{t}+\frac{\theta(B)}{\phi(B)} \varepsilon_{t} \\
\Omega(B)=\omega_{0}-\omega_{1} B-\omega_{2} B^{2} \cdots-\omega_{s} B^{s} \\
E(B)=1-\beta_{1} B-\beta_{2} B^{2} \cdots-\beta_{r} B^{r} \\
\varphi(B)=1-a_{1} B-a_{2} B^{2} \cdots-a_{P} B^{p} \\
\theta(B)=1-b_{1} B-b_{2} B^{2} \cdots-b_{q} B^{q}
\end{array}\right.
$$

where, $S F_{t}$ is the stem sap flow; $B$ is a lag operator; $X_{t}$ is independent variable; $s, r, p$ and $q$ are the orders of the model; $\Omega(B), E(B), \varphi(B)$ and $\theta(B)$ are polynomials of lag operator; $\omega_{i}, \beta_{i}, a_{i}$ and $b_{i}$ are coefficients for the polynomials; $b$ is a delay parameter; and $\varepsilon_{t}$ is the white noise.

In this paper, we used the cross-correlation function to extract maximum information inherent 
in dependent and independent variables in the model identification process, which could effectively reduce the number of parameters. We only used times of stem sap flow during 06:00-20:00 to analyze time lags of maize stem sap flow with $R_{s}$ and $V P D_{\text {air. }}$ The model orders were estimated by examining the raw data and plots of the cross-correlation function and autocorrelation and partial autocorrelation functions of the data. We used maximum likelihood to estimate the model parameters. The above processes were executed with PROC ARMA in SAS 9.2 (SAS Institute Inc., Cary, NC, USA). In order to assess the goodness of prediction of the models, we compared the predicted values $\left(P_{i}\right)$ of stem sap flow with the measured values $\left(M_{i}\right)$. The indicators of estimation errors and quality of modeling were calculated by the following indices, i.e., the root mean square error $(R M S E)$, mean absolute error $(M A E)$, and the Nash and Sutcliffe (1970) modeling efficiency $(E F)$ :

$$
\begin{gathered}
R M S E=\sqrt{\frac{1}{n} \sum_{i=1}^{n}\left(P_{i}-M_{i}\right)^{2},} \\
M A E=\frac{1}{n} \sum_{i=1}^{n}\left|P_{i}-M_{i}\right|, \\
E F=1-\frac{\sum_{i=1}^{n}\left(P_{i}-M_{i}\right)^{2}}{\sum_{i=1}^{n}\left(M_{i}-\bar{M}\right)^{2}},
\end{gathered}
$$

where, $\bar{M}$ is the measured mean value of the seed-maize stem sap flow.

We also compared the ARIMAX model with common multivariate regression model (MR) in prediction of seed-maize sap flow. The stem sap flow data on 132 DAS were used to validate the models. In multivariate regression model, the independent variables included $R_{S}$ and $V P D_{\text {air, }}$ which were the mainly positive affecting factors of seed-maize stem flow (Bo et al., 2015). Likewise, we fitted the ARIMAX model to the stem sap flow series using independent variables as predictor variables.

\section{Results and discussion}

\subsection{Seasonal patterns of stem sap flow, $R_{s}$ and $V P D_{\text {air }}$}

The seasonal variation of seed-maize stem sap flow (Fig. 1a) showed strong seasonal characteristics, with clear differences among plant growth stages. Seasonal daily sap flow varied from $64.8( \pm 6.3)$ to $919.1( \pm 49.1) \mathrm{mL} / \mathrm{d}$ for female plants, and from $63.8( \pm 7.1)$ to $854.3( \pm 30.8)$ $\mathrm{mL} / \mathrm{d}$ for male plants (Fig. 1a). For both female and male plants, daily stem sap flow had obviously declining trend with the developing stages. During the measurement periods, the lowest stem sap flow of female and male plants were found at the maturity stage (DAS 124-145). Stem sap flow of both female and male plants corresponded equally well to both $R_{s}$ and $V P D_{\text {air }}$ (Figs. $1 \mathrm{~b}$ and $\mathrm{c})$.

\subsection{Time lags between seed-maize stem sap flow and environmental factors}

Stem sap flow lagged behind $R_{s}$ but preceded changes of $V P D_{\text {air }}$ (Fig. 2). Correlation coefficients examined for lag times at 15-min time intervals indicated that the maximum correlation between stem sap flow and meteorological driving factors $\left(R_{s}\right.$ and $\left.V P D_{\text {air }}\right)$ was found when stem sap flow lagged behind $R_{s}$ (+lags of $R_{s}$ relative to stem sap flow; $15 \mathrm{~min}$ and $30 \mathrm{~min}$ time lags for female and male plants, respectively) and $V P D_{\text {air }}$ lagged behind stem sap flow (-lags of $V P D_{\text {air }}$ to stem sap flow, -105 min and -90 min for female and male plants, respectively) (Figs. 3a and b). Time lags were more strongly associated with $R_{s}$ than with $V P D_{\text {air }}$ (Figs. $3 \mathrm{a}$ and $\mathrm{b}$ ). In all comparisons of environmental variables, $V P D_{\text {air }}$ lagged behind $R_{S}$ (+lag of $R_{s}$ relative to $V P D_{\text {air }} ; 120 \mathrm{~min}$ ) for a period approximately equal to the lag between stem sap flow and $\mathrm{R}_{\mathrm{s}}$ and stem sap flow and $V P D_{\text {air }}$ (Fig. 3c). It is worth pointing out that, although $R_{s}$ appeared to be the driving factor of diurnal sap 
flow lags, both $V P D_{\text {air }}$ and $R_{s}$ appeared equally well associated with variations in daily stem sap flow (Fig. 1). The finding that $R_{s}$ was the main driver of the diurnal sap flow response confirmed other studies (Meinzer et al., 1993; Phillips et al., 1999; O’Brien et al., 2004; Oguntunde, 2005; Wang et al., 2008; Kume et al., 2010).
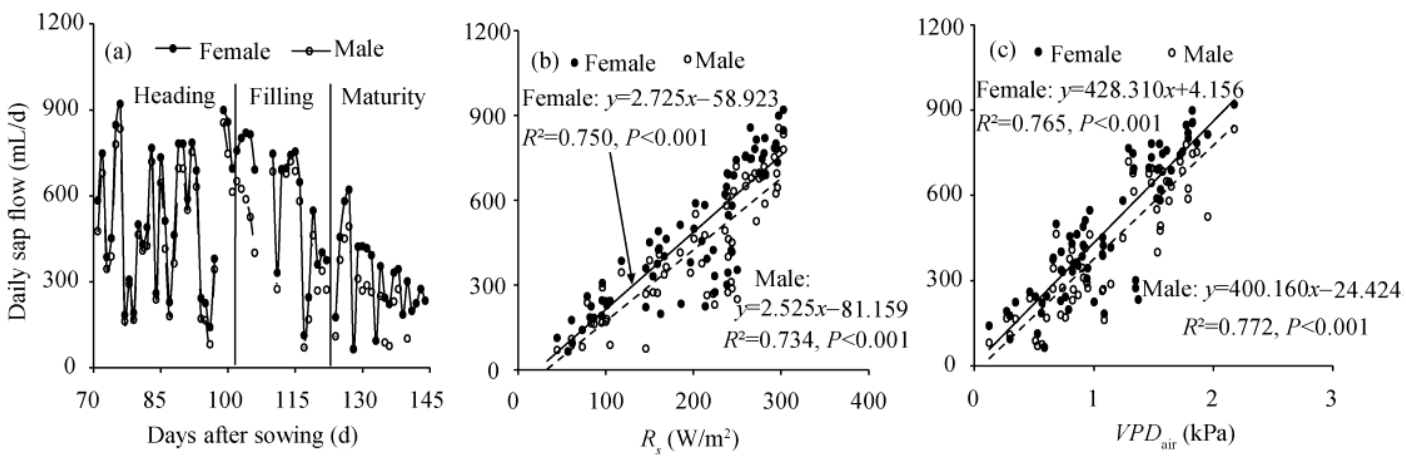

Fig. 1 Distribution of daily stem sap flow in seed-maize (a), and the linear relationship of seed-maize stem sap flow with solar radiation $\left(R_{s} ; \mathrm{b}\right)$ and vapor pressure deficit of the air $\left(V P D_{\text {air }} ; \mathrm{c}\right)$ from 71 to 145 days after sowing. Solid lines indicated the relationship of female stem sap flow with $R_{s}$ or $V P D_{\text {air }}$; dashed lines indicated the relationship of male stem sap flow with $R_{s}$ or $V P D_{\text {air. }}$.
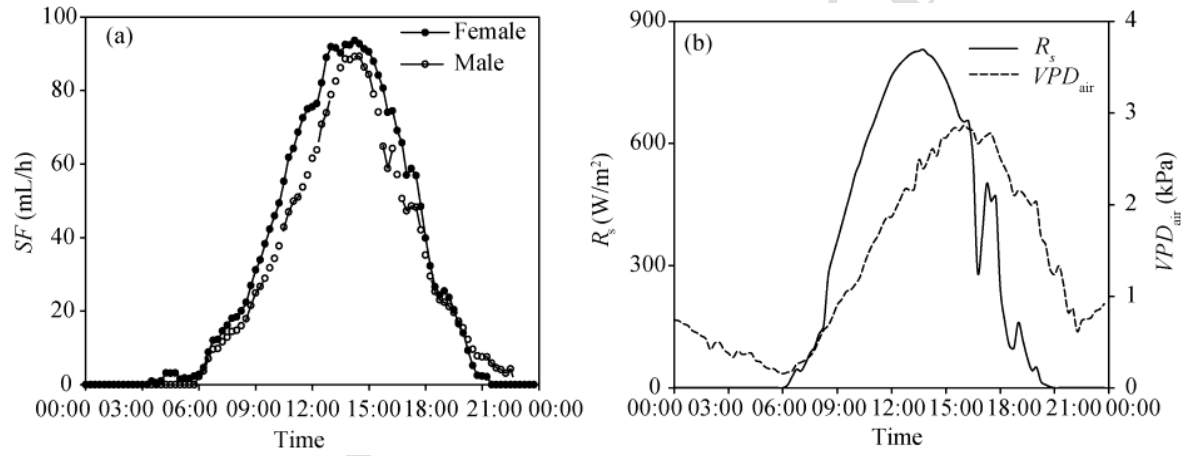

Fig. 2 Diurnal patterns of stem sap flow $(S F)$ in seed-maize (a), and diurnal patterns of solar radiation $\left(R_{s}\right)$ and vapor pressure deficit of the air $\left(V P D_{\text {air }} ; \mathrm{b}\right)$
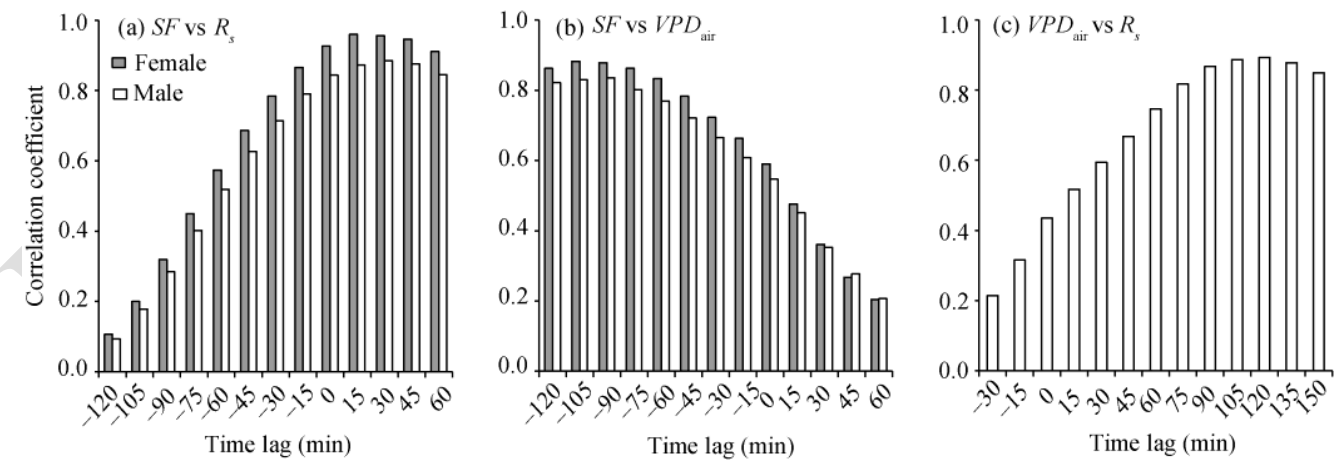

Fig. 3 Cross-correlation between stem sap flow $(S F)$ of female and male plants and $R_{S}$ (a) and $V P D_{\text {air }}$ (b), and between $V P D_{\text {air }}$ and $R_{S}$ (c) on hourly scale. Changes in $R_{s}$ preceded changes in $S F$ and $V P D_{\text {air }}$ preceded changes in $R_{s}$ (correlation with +lags), whereas $S F$ was responsive to prospective values of $V P D_{\text {air }}$ (correlation with -lags).

Data analysis indicated that time lag not only existed on hourly scale but also was significantly different among various stages (Table 1). In three growth stages, a steep increasing trend was found in the time lags of stem sap flow with $R_{s}$; the longest seasonal lags were recorded at maturity stage, with $45 \mathrm{~min}$ for female plants and $75 \mathrm{~min}$ for male plants. However, compared to 
$R_{s}$, the time lags of $V P D_{\text {air }}$ with stem sap flow gradually decreased with ontogenetic stage; the highest values were found during heading stage with 90 min for female plants and 75 min for male plants. It is worth noting that on daily basis, sap flow in seed-maize appeared to be better correlated with $V P D_{\text {air }}$ than with $R_{s}$, while on a diurnal basis, stem flow appeared to be more associated with $R_{s}$ (Figs. 3a and b). The effects of $R_{s}$ on transpiration were indirect, through the effects of photosynthetically active radiation on stomatal conductance, while $V P D_{\text {air }}$ directly affects transpiration (Phillips et al., 1999). Our comparison shows that $R_{s}$ controls the shape of the diurnal flux in seed-maize while $V P D_{\text {air }}$ controls the magnitude of daily water consumed for seed-maize plants. Seed-maize daily water use remained similar during the heading and into the grain filling stage, then began to decrease in the grain filling stage and continued to decrease as plants matured. However, lags in sap flow in response to $R_{s}$ increased across plant growth stages with distinct changes in sap flow lags in each growth state. Differences in sap flow lags were not related to plant size because the height and leaf area were stable during the observation period (Bo et al., 2015). The differences in sap flow lags in various growth stages when the plant height and leaf area were stable could be due to the changes in capacitance tissues, probably confirming that variability in lags mainly correspond to the differences in plant capacitance (Schulze et al., 1985; Martin et al., 1997; Phillips et al., 1997; Goldstein et al., 1998; O'Brien et al., 2004; Čermák et al., 2007; Dragoni et al., 2009; Liu et al., 2015). These are also concurrent with studies showing longer lags for older trees that likely have more storage capacity than for younger trees (Hogg et al., 1997; Granier et al., 2000; Ford et al., 2004) and also with plant modeling results showing that plant water storage underlays sap flow lags (Chuang et al., 2006).

Lag times of stem sap flow with $R_{s}$ and $V P D_{\text {air }}$ both on hourly and daily scales indicate differences of time lags between female and male plants (Table 1). However, stem sap flow of female plants was more responsive to $R_{s}$ (15-30 min closer) with $V P D_{\text {air }}$ lagging further behind stem sap flow (15-30 min behind) compared to male plants across the three growth stages (Table 1). We also found that time lags in female and male plants exist for woody species (Table 2). Time lags of sap flow can differ among plant species and be attributable to plant differences other than capacitance differences (Phillips et al., 1999). Studies finding variability in lags among species were more dependent on plant anatomical or physiological characteristic of the vascular system of each species (Čermák et al., 1976), which may also explain the differences found between female and male plants here. Studies show shorter lags in angiosperms compared to gymnosperms (Ford et al., 2004; Wang, 2013), which were associated with anatomical differences in their xylem leading to less hydraulic resistance in vessels of angiosperms compared to tracheids of gymnosperms (Wang, 2013). Angiosperms show particularly large variation in time lags among species with a range from 5 to 115 min (Table 2). Even for closely related species (e.g., Vitis spp. and V. vinifera), studies can show large differences in time lags (Table 3; Braun and Schmid, 1999; Phillips et al., 1999).

Table 1 Time lags $(t)$ at the maximum correlations $\left(R_{\max }\right)$ obtained by cross-correlation analysis between stem sap flow $(S F)$ and meteorological driving factors (solar radiation $\left(R_{s}\right)$ and vapor pressure deficit $\left(V P D_{\text {air }}\right)$ ) for various growth stages of female $(\mathrm{F})$ and male $(\mathrm{M})$ seed-maize

\begin{tabular}{|c|c|c|c|c|c|c|c|c|}
\hline \multirow{2}{*}{ Growth stage } & \multirow{2}{*}{ DAS } & \multirow{2}{*}{ Plant } & \multicolumn{2}{|c|}{$S F$ vs $R_{s}$} & \multicolumn{2}{|c|}{$S F$ vs $V P D_{\text {air }}$} & \multicolumn{2}{|c|}{$V P D_{\text {air }}$ vs $R_{s}$} \\
\hline & & & $t(\min )$ & $R_{\max }$ & $\mathrm{t}(\mathrm{min})$ & $R_{\max }$ & $t(\min )$ & $R_{\max }$ \\
\hline \multirow{2}{*}{ Heading stage } & \multirow{2}{*}{$71-103$} & $\mathrm{~F}$ & 15 & 0.942 & -90 & 0.789 & \multirow{2}{*}{105} & \multirow{2}{*}{0.677} \\
\hline & & M & 30 & 0.931 & -75 & 0.788 & & \\
\hline \multirow{2}{*}{ Filling stage } & \multirow{2}{*}{$104-123$} & $\mathrm{~F}$ & 30 & 0.934 & -75 & 0.843 & \multirow{2}{*}{105} & \multirow{2}{*}{0.664} \\
\hline & & M & 60 & 0.911 & -45 & 0.826 & & \\
\hline \multirow{2}{*}{ Maturity stage } & \multirow{2}{*}{$124-145$} & $\mathrm{~F}$ & 45 & 0.878 & -75 & 0.817 & \multirow{2}{*}{120} & \multirow{2}{*}{0.689} \\
\hline & & M & 75 & 0.776 & -45 & 0.690 & & \\
\hline
\end{tabular}


Table 2 Time lags between stem sap flow of various plant species and canopy transpiration $\left(T_{r}\right)$, or $R_{s}$

\begin{tabular}{|c|c|c|c|c|}
\hline Phylum & Species & Pair & $t(\min )$ & Reference \\
\hline \multirow[t]{8}{*}{ Gymnosperm } & Abies amabilis & $S F$ vs $R_{S}$ & 120 & Martin et al. (1997) \\
\hline & Pinus silvestris & $S F$ vs $R_{s}$ & $60-120$ & Čermák et al. (1995) \\
\hline & Pseudotsuga menziesii & $S F$ vs $T_{r}$ & $60-120$ & Čermák et al. (2007) \\
\hline & Pinus banksiana & $S F$ vs $T_{r}$ & 60 & Saugier et al. (1997) \\
\hline & Pinus taeda & $S F$ vs $T_{r}$ & 60 & Phillips et al. (1997) \\
\hline & Pinus pinaster & $S F$ vs $T_{r}$ & $60-90$ & Berbigier et al. (1996) \\
\hline & Pinus pinaster & $S F$ vs $T_{r}$ & 60 & Granier et al. (1990) \\
\hline & Larix \& Picea & $S F$ vs $T_{r}$ & $120-180$ & Schulze et al. (1985) \\
\hline \multirow[t]{14}{*}{ Angiosperm } & Trees & & & \\
\hline & Phyllostachys pubescens & $S F$ vs $R_{s}$ & 30 & Kume et al. (2010) \\
\hline & Eucalyptus crebra & $S F$ vs $R_{s}$ & 60 & Zeppel et al. (2008) \\
\hline & Anacardium excelsum & $S F$ vs $R_{s}$ & $60-115$ & Phillips et al. (1999) \\
\hline & Antirrhoea trichantha & $S F$ vs $R_{s}$ & $5-60$ & Phillips et al. (1999) \\
\hline & Luehea seemannii & $S F$ vs $R_{s}$ & $35-60$ & Phillips et al. (1999) \\
\hline & Phoebe mexicana & $S F$ vs $R_{s}$ & 40 & Phillips et al. (1999) \\
\hline & Zuelania guidonia & $S F$ vs $R_{s}$ & 10 & Phillips et al. (1999) \\
\hline & Dipterocarpus pachyphyllus & $S F$ vs $T_{r}$ & 20 & Kume et al. (2008) \\
\hline & Quercus petraea & $S F$ vs $T_{r}$ & 30 & Granier and Bréda (1996) \\
\hline & Lianas & & & \\
\hline & Combretum spp. & $S F$ vs $R_{S}$ & 10 & Phillips et al. (1999) \\
\hline & Vitis spp. & $S F$ vs $R_{s}$ & 5 & Phillips et al. (1999) \\
\hline & Vitis vinifera & $S F$ vs $T_{r}$ & 20 & Braun and Schmid (1999) \\
\hline
\end{tabular}

\subsection{Relationship between time lags and stored water use}

Daily stored water use increased as time lags of sap flow to $R_{s}$ increased in a significant linear fashion for both female and male plants (Fig. 4). A similar amount of daily stored water use was found between female and male plants when they had the same time lag. Total daily water consumed in female plants was higher than in male plants. Stored water use represented 5.8\% to $23.5 \%$ of daily water loss in female plants (Fig. $4 \mathrm{a}$ ), and $8.8 \%$ to $25.2 \%$ in male plants (Fig. $4 \mathrm{~b}$ ). Compared to female plants, the higher proportion of stored water use in male plants was attributed to lower daily water consumption since daily stored water was similar between female plants and male plants.

Water storage may provide a mechanism of self-protection for plants to avoid damage caused by excessive water loss (Chen et al., 2011). Stored water may be not a significant source of water for transpiration in most plants (Tyree and Yang, 1990), but can contribute a significant proportion of the total diurnal water use under severe droughts (Čermák et al., 1982; Goldstein et al., 1984). In cropping systems, stored water may play an important role in supporting sap flow and carbon fixation during droughts. The correlation of sap flow lags to stored water use found in seed-maize plants suggests that the lags of sap flow with $R_{s}$ are mainly dependent on plant capacitance. If the upper foliage was representative of the canopy transpiration, stem flow-radiation lags should match well with the sum of stem flow-upper foliage transpiration and upper foliage transpiration-radiation lags for seed-maize plants. The time lags between basal stem 
flow and transpiration are generally explained by hydraulic capacitance and resistance $(\mathrm{O}$ 'Brien et al., 2004; Čermák et al., 2007; Kume et al., 2008), while the transpiration-radiation lags are mainly dependent on the energy balance in the canopy and controlled by stomatal conductance. In other words, the combined effects of hydraulic capacitance and stomatal dynamics resulted in longer lags for seed-maize stem flow in response to $R_{s}$. Meanwhile, the high correlation of time lags to stored water use indicated that the contribution of hydraulic capacitance may be more significant than the contribution of stomatal conductance.
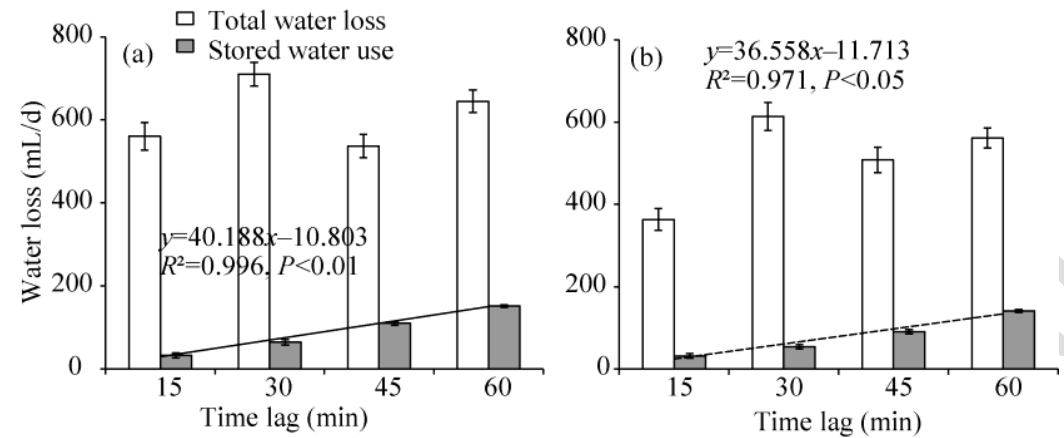

Fig. 4 Total daily water loss and fraction of that water taken up by female (a) and male plants (b) in the evening. Values represent means of daily stored water use or daily total water loss for days with the same time lag during the observation period.

\subsection{Effect of soil water status on time lags}

Table 3 lists the time lags $(t)$ and the maximum correlations $\left(R_{\max }\right)$ of stem sap flow in female and male seed-maize with meteorological driving factors before irrigation and after irrigation. The maximum cross-correlation coefficients were systemically higher after irrigation than before irrigation. In female plants, there was no change in time lags between stem sap flow and $R_{s}$ before irrigation and after irrigation. In contrast, stem sap flow response to $R_{s}$ in male plants was slower after irrigation than before irrigation, and likewise more internal water storage would be used for transpiration after irrigation (Table 3). Interestingly, stem sap flow in both female and male plants responded more quickly to $R_{s}$ (greater lags in $V P D_{\text {air }}$ compared to stem sap flow) before than after irrigation.

Theoretically, dry soil can cause the increase in plant hydraulic resistance (Sperry and Pockman, 1993; Wullschleger et al., 1998), and trigger stomatal closure, which can then increase sap flow time lags (Cienciala et al., 1994; Kumagai, 2001). In some cases, time lags of tree sap flow also had no clear patterns related to soil water status (Kume et al., 2008; Dragoni et al., 2009; Chen et al., 2011). However, female and male plants in the present study differed in their response of stem sap flow to $R_{s}$ between before irrigation and after irrigation with female plants showing a lack of effect of soil moisture compared with male plants, which had shorter lags and used less internal water storage when soil was dry. Although canopy transpiration is often limited by water availability (Meinzer et al., 1993; Sala and Tenhunen, 1996), for most plants, substantial declines of field capacity can occur in soil water levels before time lags of plant sap flow are affected. How dry soil affects lag times in sap flow may not be straight forward since soil moisture deficit generally affects plant stem flow at different temporal scales than the main environmental factors of stem flow. Furthermore, in cropping systems with deficit irrigation, additional mechanisms governing plant responses could indirectly affect time lag in plant sap flow and these mechanisms may include hormonal signals in root systems experiencing periodic water availability that increase root water uptake capacity and decrease plant hydraulic resistance (Dry and Loveys, 1998; Davies et al., 2011; Du et al., 2015). Differences found here in response of stem sap flow to $R_{s}$ before irrigation and after irrigation between female and male plants may have been fortuitous or may be related to physiological differences between them. 
Table 3 Time lags $(t)$ and the maximum correlations $\left(R_{\max }\right)$ of stem sap flow in female $(\mathrm{F})$ and male $(\mathrm{M})$ seed-maize with meteorological driving factors before irrigation (BI) and after irrigation (AI)

\begin{tabular}{|c|c|c|c|c|c|c|c|c|}
\hline \multirow{2}{*}{ Period } & \multirow{2}{*}{ Plant } & \multirow{2}{*}{$\begin{array}{l}\theta_{\text {avg }} \\
\left(\mathrm{cm}^{3} / \mathrm{cm}^{3}\right)\end{array}$} & \multirow{2}{*}{$\begin{array}{l}S F_{a v g} \\
(\mathrm{~mL} / \mathrm{d})\end{array}$} & \multirow{2}{*}{$\begin{array}{l}S W U_{a v g} \\
(\mathrm{~mL} / \mathrm{d})\end{array}$} & \multicolumn{2}{|c|}{$S F$ vs $R_{s}$} & \multicolumn{2}{|c|}{$S F$ vs $V P D_{\text {air }}$} \\
\hline & & & & & $t(\min )$ & $R_{\max }$ & $t(\min )$ & $R_{\max }$ \\
\hline \multirow[t]{2}{*}{ AI } & $\mathrm{F}$ & 0.248 & 775.2 & 33.6 & 15 & 0.909 & -60 & 0.802 \\
\hline & M & 0.243 & 644.5 & 44.7 & 30 & 0.915 & -45 & 0.840 \\
\hline \multirow[t]{2}{*}{ BI } & $\mathrm{F}$ & 0.214 & 770.8 & 36.3 & 15 & 0.879 & -75 & 0.688 \\
\hline & M & 0.216 & 555.7 & 35.4 & 15 & 0.802 & -60 & 0.649 \\
\hline
\end{tabular}

Note: Values of $\theta_{\text {avg }}, S F_{\text {avg }}$ and $S W U_{\text {avg }}$ represent averages of soil water content, daily stem sap flow, and stored water use in each period, respectively.

\subsection{Performance of transfer function model in seed-maize stem sap flow prediction}

Time series analysis methods, which are commonly used in hydrology, meteorology, economics, and demography, performed well for simulating the physiological responses of seed-maize sap flow. The transfer function model used here allows for prediction of dependent variables using the information extracted from these variables. Other studies using transfer function models for simulating sap flow in trees found a systematic underestimate compared to measured values (Ford et al., 2004). For the ARIMAX and MR models, $V P D_{\text {air }}$ explained more variance in stem sap flow than $R_{s}$. The performance of these models in predicting stem sap flow was evaluated by comparing measured data with simulated values. Regression coefficients indicated that there was a close agreement between measured and simulated data for both models. For both models, the coefficients designating fits were larger than 1 , indicating that the simulated values overestimated the observed ones. The coefficient of determination $\left(R^{2}\right)$ ranged from 0.803 to 0.928 , indicating that both models effectively explained the variance in stem sap flow. Comparing coefficients of the two models, the ARIMAX model did better than MR model in predicting stem sap flow and explaining variance in stem sap flow (i.e., coefficients for both fit and determination were closer to 1) (Fig. 5). Error estimation indicators for the ARIMAX model were low for modeling stem sap flow for both female and male plants (Table 4).

Our study showed that the simulated values were slightly higher than the observed values. This difference could be attributed to the continuous reduction of soil water availability during the observation period. In general, a strong relationship of transpiration with soil water is found under low soil water availability (Granier and Loustau, 1994; Bauerle et al., 2002). When used to predict canopy transpiration during a dry period, the ARIMAX model parameterized without soil water limitations did not perform well and showed a systematic overestimate (Ford et al., 2005). By assessing the goodness of fit indicators for the transfer function model, it can be concluded that transfer function model had fairly good performance for predicting the seed-maize sap flow,
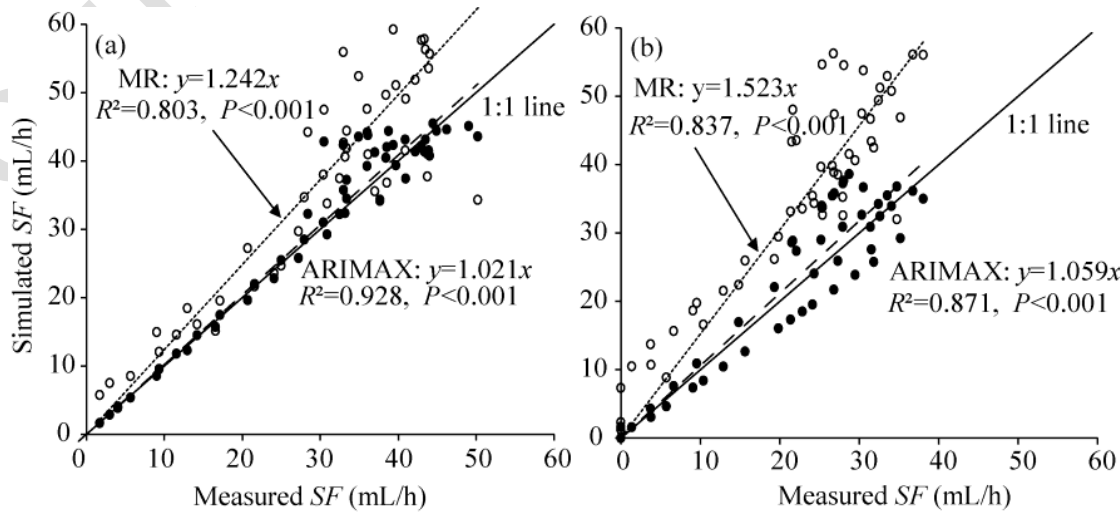

Fig. 5 Comparison between stimulated and measured stem sap flow (SF) of female (a) and male plants (b) for ARIMAX model and multivariate regression (MR) model. Dotted lines indicate the linear relationship between predicted data from MR model and measured stem sap flow; dashed lines indicated the linear relationship between stimulated data from ARIMAX model and measured stem sap flow. 
Table 4 Goodness of fit indicators for comparisons between measured values of stem sap flow in female (F) and male (M) seed-maize and those predicted by the time series

\begin{tabular}{ccccc}
\hline Plant & Equation & $\begin{array}{c}R M S E \\
(\mathrm{~mL} / \mathrm{h})\end{array}$ & $\begin{array}{c}M A E \\
(\mathrm{~mL} / \mathrm{h})\end{array}$ & $E F$ \\
$\mathrm{~F}$ & $S F_{t}=\frac{7.969-9.012 B}{1-1.419 B+0.432 B^{2}} V P D_{\text {air }}+\frac{1}{\left(1-0.048 B+0.133 B^{2}\right)(1-B)} \varepsilon_{t}$ & 3.65 & 2.44 & 0.921 \\
$\mathrm{M}$ & $S F_{t}=\frac{1.178-3.196 B+1.733 B^{2}}{1-1.931 B+0.934 B^{2}} V P D_{\text {air }}+\frac{1}{\left(1+0.190 B+0.086 B^{2}\right)(1-B)} \varepsilon_{t}$ & 4.71 & 3.65 & 0.822 \\
\hline
\end{tabular}

Note: $R M S E$, root mean square error; $M A E$, mean absolute error; $E F$, modeling efficiency.

particularly given that common empirical models rarely accurately predict stem sap flow data due to the serial dependence inherent in stem sap flow data. Nonetheless, care should be taken in applying the orders and parameters obtained here to simulate sap flow in other studies of seed-maize due to different environmental conditions and irrigation methods. Furthermore, in spite of the good performance of the transfer function model, the impact of irrigation and rainfall events should be taken into account for the improvement of the models in the upcoming research.

\section{Conclusions}

Examining sap flow responses to meteorological driving variables provided us insights into mechanisms regulating plant water use. Our results clearly demonstrate that time lags not only existed on hourly scale, but the lags differed significant among various stages. $R_{s}$ controls the shape of the diurnal flux in seed-maize while $V P D_{\text {air }}$ controls the magnitude of daily water consumed for seed-maize plants. We found that plant capacitance tissues play a large role in supporting daily sap flow in maize as they do in trees. While capacitance tissues cannot support plants during drought periods, the role of capacitance tissues in sustaining daily sap flow at times of insufficient intrinsic water uptake capacity implores further investigation. In this study, female plants response of stem sap flow to $R_{s}$ before irrigation and after irrigations showing a lack of effect of soil moisture compared with male plants, the latter (male plants) having shorter lags and used less internal water storage when soil was dry. The time series analysis method used in this present study showed a promising potential for identifying relationships between variables and serial dependence inherent in stem sap flow data.

\section{Acknowledgements}

We are grateful for the support from the National Key Basic Research Program of China (2016YFC0400207), the National Natural Science Foundation of China (51439006, 91425302) and the 111 Program of Introducing Talents of Discipline to Universities (B14002). We thank Sean GLEASON and Frederick MEINZER for suggestions that improved the clarity of this manuscript.

\section{References}

Alarcón J J, Domingo R, Green S R, et al. 2003. Estimation of hydraulic conductance within field-grown apricot using sap flow measurements. Plant and Soil, 251(1): 125-135.

Allen R G, Pereira L S, Raes D, et al. 1998. Crop evapotranspiration-guidelines for computing crop water requirement. In: FAO Irrig and Drain Paper No. 56. Rome, Italy.

Baker J M, van Bavel C H M. 1987. Measurement of mass flow of water in the stems of herbaceous plants. Plant, Cell \& Environment, 10(9): 777-782.

Bauerle W L, Post C J, McLeod M F, et al. 2002. Measurement and modeling of the transpiration of a temperate red maple container nursery. Agricultural and Forest Meteorology, 114(1-2): 45-57.

Berbigier P, Bonnefond J M, Loustau D, et al. 1996. Transpiration of a 64-year old maritime pine stand in Portugal. Oecologia, 107(1): 43-52.

Bo X D, Du T S, Ding R S, et al. 2015. Stem flow of seed-maize under alternate furrow irrigation and double-row ridge planting in an arid region of Northwest China. Journal of Integrative Agriculture, 14(7): 1434-1445.

Borchert R. 1994. Soil and stem water storage determine phenology and distribution of tropical dry forest trees. Ecology, 75(5): 
$1437-1449$.

Box G E P, Jenkins G M. 1976. Time Series Analysis: Forecasting and Control. Oakland: Holden-Day, 7-19.

Braun P, Schmid J. 1999. Sap flow measurements in grapevines (Vitis vinifera L.) 2. Granier measurements. Plant and Soil, 215(1): 47-55.

Čermák J, Kučera J, Penka M. 1976. Improvement of the method of sap flow rate determination in full-grown trees based on heat balance with direct electric heating of xylem. Biologia Plantarum, 18(2): 105-110.

Čermák J, Úlehla J, Kučera J, et al. 1982. Sap flow rate and transpiration dynamics in the full-grown oak (Quercus robus L.) in floodplain forest exposed to seasonal floods as related to potential evapotranspiration and tree dimensions. Biologia Plantarum, 24(6): 446-460.

Čermák J, Cienciala E, Kučera J, et al. 1995. Individual variation of sap-flow rate in large pine and spruce trees and stand transpiration: a pilot study at the central NOPEX site. Journal of Hydrology, 168(1-4): 17-27.

Čermák J, Kučera J, Bauerle W L, et al. 2007. Tree water storage and its diurnal dynamics related to sap flow and changes in stem volume in old-growth Douglas-fir trees. Tree Physiology, 27(2): 181-198.

Chang X X, Zhao W Z, Zhang Z H, et al. 2006. Sap flow and tree conductance of shelter-belt in arid region of China. Agricultural and Forest Meteorology, 138(1-4): 132-141.

Chen L X, Zhang Z Q, Li Z D, et al. 2011. Biophysical control of whole tree transpiration under an urban environment in Northern China. Journal of Hydrology, 402(3-4): 388-400.

Chirino E, Bellot J, Sánchez J R. 2011. Daily sap flow rate as an indicator of drought avoidance mechanisms in five Mediterranean perennial species in semi-arid southeastern Spain. Trees, 25(4): 593-606.

Chuang Y L, Oren R, Bertozzi A L, et al. 2006. The porous media model for the hydraulic system of a conifer tree: linking sap flux data to transpiration rate. Ecological Modelling, 191(3-4): 447-468.

Cienciala E, Eckersten H, Lindroth A, et al. 1994. Simulated and measured water uptake by Picea abies under non-limiting soil water conditions. Agricultural and Forest Meteorology, 71(1-2): 147-164.

Corona R, Curreli M, Montaldo N, et al. 2013. On the estimate of the transpiration in Mediterranean heterogeneous ecosystems with the coupled use of eddy covariance and sap flow techniques. In: EGU General Assembly 2013. Vienna, Austria: EGU, 15: 11449 .

Cuevas M V, Martín-Palomo M J, Diaz-Espejo A, et al. 2013. Assessing water stress in a hedgerow olive orchard from sap flow and trunk diameter measurements. Irrigation Science, 31(4): 729-746.

Davies W J, Zhang J H, Yang J, et al. 2011. Novel crop science to improve yield and resource use efficiency in water-limited agriculture. The Journal of Agricultural Science, 149(Suppl.): 123-131.

De Swaef T, Verbist K, Cornelis W, et al. 2012. Tomato sap flow, stem and fruit growth in relation to water availability in rockwool growing medium. Plant and Soil, 350(1-2): 237-252.

Diawara A, Loustau D, Berbigier P. 1991. Comparison of two methods for estimating the evaporation of a Pinus pinaster (Ait.) stand: sap flow and energy balance with sensible heat flux measurements by an eddy covariance method. Agricultural and Forest Meteorology, 54(1): 49-66.

Dragoni D, Caylor K K, Schmid H P. 2009. Decoupling structural and environmental determinants of sap velocity: part II. observational application. Agricultural and Forest Meteorology, 149(3-4): 570-581.

Dry P R, Loveys B R. 1998. Factors influencing grapevine vigour and the potential for control with partial rootzone drying. Australian Journal of Grape and Wine Research, 4(3): 140-148.

Du T S, Kang S Z, Zhang J H, et al. 2015. Deficit irrigation and sustainable water-resource strategies in agriculture for China's food security. Journal of Experimental Botany, 66(8): 2253-2269.

Dye P J, Olbrich B W. 1993. Estimating transpiration from 6-year-old Eucalyptus grandis trees: development of a canopy conductance model and comparison with independent sap flux measurements. Plant, Cell \& Environment, 16(1): 45-53.

Dzikiti S, Steppe K, Lemeur R, et al. 2007. Whole-tree level water balance and its implications on stomatal oscillations in orange trees [Citrus sinensis (L.) Osbeck] under natural climatic conditions. Journal of Experimental Botany, 58(7): 1893-1901.

Edwards W R N, Jarvis P G, Landsberg J J, et al. 1986. A dynamic model for studying flow of water in single trees. Tree Physiology, 1(3): 309-324.

Ewers B E, Oren R. 2000. Analyses of assumptions and errors in the calculation of stomatal conductance from sap flux measurements. Tree Physiology, 20(9): 579-589.

Ford C R, Goranson C E, Mitchell R J, et al. 2004. Diurnal and seasonal variability in the radial distribution of sap flow: predicting total stem flow in Pinus taeda trees. Tree Physiology, 24(9): 951-960.

Ford C R, Goranson C E, Mitchell R J, et al. 2005. Modeling canopy transpiration using time series analysis: a case study 
illustrating the effect of soil moisture deficit on Pinus taeda. Agricultural and Forest Meteorology, 130(3-4): 163-175.

Goldstein G, Meinzer F, Monasterio M. 1984. The role of capacitance in the water balance of Andean giant rosette species. Plant, Cell \& Environment, 7(3): 179-186.

Goldstein G, Andrade J L, Meinzer F C, et al. 1998. Stem water storage and diurnal patterns of water use in tropical forest canopy trees. Plant, Cell \& Environment, 21(4): 397-406.

Gong D Z, Kang S Z, Yao L M, et al. 2007. Estimation of evapotranspiration and its components from an apple orchard in northwest China using sap flow and water balance methods. Hydrological Processes, 21(7): 931-938.

Granier A, Bobay V, Gash J H C, et al. 1990. Vapour flux density and transpiration rate comparisons in a stand of Maritime pine (Pinus pinaster Ait.) in Les Landes forest. Agricultural and Forest Meteorology, 51(3-4): 309-319.

Granier A, Loustau D. 1994. Measuring and modelling the transpiration of a maritime pine canopy from sap-flow data. Agricultural and Forest Meteorology, 71(1-2): 61-81.

Granier A, Bréda N. 1996. Modelling canopy conductance and stand transpiration of an oak forest from sap flow measurements. Annales des Sciences Forestières, 53(2-3): 537-546.

Granier A, Biron P, Lemoine D. 2000. Water balance, transpiration and canopy conductance in two beech stands. Agricultural and Forest Meteorology, 100(4): 291-308.

Hinckley T M, Lassoie J P, Running S W. 1978. Temporal and spatial variations in the water status of forest trees. Forest Science, 24(3): a0001-z0001.

Hinckley T M, Sprugel D G, Brooks J R. 1998. Scaling and Integration in trees. In: Peterson D L, Parker V T. Ecological Scale: Theory and Applications. New York: Columbia University Press, 309-337.

Hogg E H, Black T A, den Hartog G, et al. 1997. A comparison of sap flow and eddy fluxes of water vapor from a boreal deciduous forest. Journal of Geophysical Research: Atmospheres (1984-2012), 102(D24): 28929-28937.

Hunt E R, Nobel P S. 1987. Non-steady-state water flow for three desert perennials with different capacitances. Australian Journal of Plant Physiology, 14(4): 363-375.

Kjelgaard J F, Stockle C O, Black R A, et al. 1997. Measuring sap flow with the heat balance approach using constant and variable heat inputs. Agricultural and Forest Meteorology, 85(3-4): 239-250.

Köstner B M M, Schulze E D, Kelliher F M, et al. 1992. Transpiration and canopy conductance in a pristine broad-leaved forest of Nothofagus: an analysis of xylem sap flow and eddy correlation measurements. Oecologia, 91(3): 350-359.

Kumagai T. 2001. Modeling water transportation and storage in sapwood-model development and validation. Agricultural and Forest Meteorology, 109(2): 105-115.

Kume T, Komatsu H, Kuraji K, et al. 2008. Less than 20-min time lags between transpiration and stem sap flow in emergent trees in a Bornean tropical rainforest. Agricultural and Forest Meteorology, 148(6-7): 1181-1189.

Kume T, Onozawa Y, Komatsu H, et al. 2010. Stand-scale transpiration estimates in a Moso bamboo forest: (I) applicability of sap flux measurements. Forest Ecology and Management, 260(8): 1287-1294.

Kume T, Otsuki K, Du S, et al. 2012. Spatial variation in sap flow velocity in semiarid region trees: its impact on stand-scale transpiration estimates. Hydrological Processes, 26(8): 1161-1168.

Landsberg J J, Blanchard T W, Warrit B. 1976. Studies on the movement of water through apple trees. Journal of Experimental Botany, 27(4): 579-596.

Lhomme J P, Rocheteau A, Ourcival J M, et al. 2001. Non-steady-state modelling of water transfer in a Mediterranean evergreen canopy. Agricultural and Forest Meteorology, 108(1): 67-83.

Liu H J, Cohen S, Lemcoff J H, et al. 2015. Sap flow, canopy conductance and microclimate in a banana screenhouse. Agricultural and Forest Meteorology, 201: 165-175.

Maherali H, DeLucia E H. 2001. Influence of climate-driven shifts in biomass allocation on water transport and storage in ponderosa pine. Oecologia, 129(4): 481-491.

Martin T A, Brown K J, Cermák J, et al. 1997. Crown conductance and tree and stand transpiration in a second-growth Abies amabilis forest. Canadian Journal of Forest Research, 27(6): 797-808.

Martin T A, Brown K J, Kučera J, et al. 2001. Control of transpiration in a 220-year-old Abies amabilis forest. Forest Ecology and Management, 152(1-3): 211-224.

Meinzer F C, Goldstein G, Holbrook N M, et al. 1993. Stomatal and environmental control of transpiration in a lowland tropical forest tree. Plant, Cell \& Environment, 16(4): 429-436.

Meinzer F C, James S A, Goldstein G. 2004. Dynamics of transpiration, sap flow and use of stored water in tropical forest canopy trees. Tree Physiology, 24(8): 901-909.

Meinzer F C, Woodruff D R, Domec J C, et al. 2008. Coordination of leaf and stem water transport properties in tropical forest trees. Oecologia, 156(1): 31-41. 
Morikawa Y. 1974. Sap flow in Chamaecyparis obtusa in relation to water economy of woody plants. Bulletin of the Tokyo University Forests, 66: 251-297.

Motzer T, Munz N, Küppers M, et al. 2005. Stomatal conductance, transpiration and sap flow of tropical montane rain forest trees in the southern Ecuadorian Andes. Tree Physiology, 25(10): 1283-1293.

Nash J E, Sutcliffe J V. 1970. River flow forecasting through conceptual models part I-a discussion of principles. Journal of Hydrology, 10(3): 282-290.

Nicolas E, Torrecillas A, Ortuño M F, et al. 2005. Evaluation of transpiration in adult apricot trees from sap flow measurements. Agricultural Water Management, 72(2): 131-145.

O'Brien J J, Oberbauer S F, Clark D B. 2004. Whole tree xylem sap flow responses to multiple environmental variables in a wet tropical forest. Plant, Cell \& Environment, 27(5): 551-567.

Oguntunde P G. 2005. Whole-plant water use and canopy conductance of cassava under limited available soil water and varying evaporative demand. Plant and Soil, 278(1-2): 371-383.

Oren R, Zimmermann R, Terborgh J. 1996. Transpiration in upper Amazonia floodplain and upland forests in response to drought-breaking rains. Ecology, 77(3): 968-973.

Oren R, Sperry J S, Katul G G, et al. 1999. Survey and synthesis of intra- and interspecific variation in stomatal sensitivity to vapour pressure deficit. Plant, Cell \& Environment, 22(12): 1515-1526.

Paudel I, Naor A, Gal Y, et al. 2015. Simulating nectarine tree transpiration and dynamic water storage from responses of leaf conductance to light and sap flow to stem water potential and vapor pressure deficit. Tree Physiology, 35(4): 425-438.

Perämäki M, Nikinmaa E, Sevanto S, et al. 2001. Tree stem diameter variations and transpiration in Scots pine: an analysis using a dynamic sap flow model. Tree Physiology, 21(12-13): 889-897.

Phillips N, Nagchaudhuri A, Oren R, et al. 1997. Time constant for water transport in loblolly pine trees estimated from time series of evaporative demand and stem sapflow. Trees, 11(7): 412-419.

Phillips N, Oren R, Zimmermann R, et al. 1999. Temporal patterns of water flux in trees and lianas in a Panamanian moist forest. Trees, 14(3): 116-123.

Phillips N G, Ryan M G, Bond B J, et al. 2003. Reliance on stored water increases with tree size in three species in the Pacific Northwest. Tree Physiology, 23(4): 237-245.

Phillips N G, Scholz F G, Bucci S J, et al. 2009. Using branch and basal trunk sap flow measurements to estimate whole-plant water capacitance: comment on Burgess and Dawson (2008). Plant and Soil, 315(1-2): 315-324.

Sakuratani T. 1981. A heat balance method for measuring water flux in the stem of intact plants. Journal of Agricultural Meteorology, 37(1): 9-17.

Sala A, Tenhunen J D. 1996. Simulations of canopy net photosynthesis and transpiration in Quercus ilex L. under the influence of seasonal drought. Agricultural and Forest Meteorology, 78(3-4): 203-222.

Saugier B, Granier A, Pontailler J Y, et al. 1997. Transpiration of a boreal pine forest measured by branch bag, sap flow and micrometeorological methods. Tree Physiology, 17(8-9): 511-519.

Schulte E D. 1993. Tissue hydraulic properties and the water relations of desert shrubs. In: Smith J A C, Griffiths H. Water Deficits, Plant Responses from Cell to Community. Environmental Plant Biology Series. Oxford: Bios Scientific Press Ltd., 177-192.

Schulze E D, Čermák J, Matyssek M, et al. 1985. Canopy transpiration and water fluxes in the xylem of the trunk of Larix and Picea trees-a comparison of xylem flow, porometer and cuvette measurements. Oecologia, 66(4): 475-483.

Sellami M H, Sifaoui M S. 2003. Estimating transpiration in an intercropping system: measuring sap flow inside the oasis. Agricultural Water Management, 59(3): 191-204.

Sperry J S, Pockman W T. 1993. Limitation of transpiration by hydraulic conductance and xylem cavitation in Betula occidentalis. Plant, Cell \& Environment, 16(3): 279-287.

Steinberg S L, Mcfarland M J, Worthington J W. 1990. Comparison of trunk and branch sap flow with canopy transpiration in pecan. Journal of Experimental Botany, 41(6): 653-659.

Steppe K, Lemeur R. 2004. An experimental system for analysis of the dynamic sap-flow characteristics in young trees: results of a beech tree. Functional Plant Biology, 31(1): 83-92.

Steppe K, De Pauw D J W, Doody T M, et al. 2010. A comparison of sap flux density using thermal dissipation, heat pulse velocity and heat field deformation methods. Agricultural and Forest Meteorology, 150(7-8): 1046-1056.

Stewart C M. 1967. Moisture content of living trees. Nature, 214(5084): 138-140.

Stratton L, Goldstein G, Meinzer F C. 2000. Stem water storage capacity and efficiency of water transport: their functional significance in a Hawaiian dry forest. Plant, Cell \& Environment, 23(1): 99-106.

Trambouze W, Bertuzzi P, Voltz M. 1998. Comparison of methods for estimating actual evapotranspiration in a row-cropped 
vineyard. Agricultural and Forest Meteorology, 91(3-4): 193-208.

Tyree M T, Yang S D. 1990. Water-storage capacity of Thuja, Tsuga and Acer stems measured by dehydration isotherms. Planta, 182(3): 420-426.

Vellame L M, Coelho Filho M A, Paz V P S, et al. 2010. Stem heat balance method to estimate transpiration of young orange and mango plants. Revista Brasileira de Engenharia Agrícola e Ambiental, 14(6): 594-599.

Villalobos F J, Testi L, Orgaz F, et al. 2013. Modelling canopy conductance and transpiration of fruit trees in Mediterranean areas: a simplified approach. Agricultural and Forest Meteorology, 171-172: 93-103.

Wang H, Zhao P, Cai X A, et al. 2008. Time lag effect between stem sap flow and photosynthetically active radiation, vapor pressure deficit of Acacia mangium. Chinese Journal of Applied Ecology, 19(2): 225-230. (in Chinese)

Wang S G. 2013. Plant Physiology. Beijing: Science Press, 68-69. (in Chinese)

Wullschleger S D, Meinzer F C, Vertessy R A. 1998. A review of whole-plant water use studies in tree. Tree Physiology, 18(8-9): 499-512.

Zeppel M J B, Macinnis-Ng C M O, Yunusa I A M, et al. 2008. Long term trends of stand transpiration in a remnant forest during wet and dry years. Journal of Hydrology, 349(1-2): 200-213. 